\title{
Institutional Field Dynamics and the Competition Between Institutional Logics
}

\section{The Role of Rhetoric in the Evolving Control of the Modern Corporation}

\author{
Sandy Edward Green Jr. \\ University of Southern California \\ Marin Babb \\ Stanford University \\ C. Murat Alpaslan \\ California State University, Northridge
}

\begin{abstract}
The authors examine how competing institutional logics shape institutional fields. Specifically, they conceptualize control of the modern corporation as an evolving institutional field. They connect changes in the institutional field to the rhetoric and corresponding logics put forth by various corporate stakeholders vying for control of the firm. Changes in the corporate institutional field are represented as the diffusion of takeovers and takeover defenses. Corporate control rhetoric is traced in interviews with corporate board members. The authors argue that the rhetoric of corporate control shapes and establishes dominant stakeholder groups in the institutional field. They conclude with a brief discussion of their analysis and a call for further research.
\end{abstract}

Keywords: institutional theory; rhetorical analysis; corporate governance

The few, however, have seldom been satisfied to command without a higher justification even when they abjured all interest in ideas, and the many have seldom been docile enough not to provoke such justifications.

-R. Bendix (2001, p. 1)

\footnotetext{
Authors' Note: The authors are extremely grateful to Professor Jay Lorsch, Professor Nitin Nohria, and the Harvard Business School Research Division for funding as well as facilitating access and contact with interviewees. The authors would also like to thank Professor John Coates at the Harvard Law School for his insightful comments and guidance. The authors are responsible for all remaining errors and omissions.
} 
How does discourse or language shape the reproduction of practices and structures within an institutional field? Some institutional accounts emphasize how language shapes institutional order. These accounts show how similar practices and structures persist because they provide legitimacy and resources when they reflect the discursive myths and institutional logics of the larger social environment (Douglas, 1986; Friedland \& Alford, 1991; Meyer \& Rowan, 1991; Strang \& Meyer, 1994, pp. 100-105). Other institutional accounts emphasize how language shapes institutional change. Within this framework, social actors are institutional entrepreneurs who purposefully use language to shape the institutional logics that legitimate the social structures and practices that constitute a social field (Clemens \& Cook, 1999; Creed, Scully, \& Austin, 2002, pp. 476-481; DiMaggio, 1988, p. 14; Fligstein, 1997, 2001; Suddaby \& Greenwood, 2005).

Although both institutional accounts suggest institutional change and order is influenced by linguistic or symbolic factors, several scholars argue that the specifics of this process are underexplained (Berger \& Luckmann, 1966, p. 64; Douglas, 1986; Friedland \& Alford, 1991; Strang \& Meyer, 1994). Specifically, institutional logics are theorized to change the social relationships, interactions, and practices that make up an institutional field, yet few studies explicitly show how institutional actors deliberately use language to support or change institutional logics (Mohr, 1998; Suddaby \& Greenwood, 2005). This article addresses this shortcoming by integrating rhetorical theory with neo-institutional theory to demonstrate how rhetorical strategies are used to support and criticize the logics that legitimize the practices and structures of an institutional field.

To illustrate our ideas, we conduct a rhetorical analysis of corporate control discourse from 1978 to 1998 . We conceptualize control of the modern corporation as an evolving institutional field in which various stakeholder groups (e.g., employees, managers, shareholders, etc.) make claims on the firm and compete for authority over the use and dispensation of corporate assets. We connect changes in actual authority and control of the firm to the rhetoric put forth by various corporate stakeholders vying for control. We argue that corporate control rhetoric shapes the institutional logics of control and thus legitimizes the dominant stakeholder group in the institutional field. We trace corporate control rhetoric in interviews with board members during their decision to adopt an important control practice: takeover defenses. We conclude with a brief discussion of our analysis and a call for further research. 


\section{Literature Review}

\section{Institutional Fields as Political Arenas}

A field is a recognized area of expertise or activity (DiMaggio \& Powell, 1991, p. 64). Neo institutionalists theorize that the professions, competition, or the state structure actors or organizations into fields. Once structured into a field, powerful isomorphic forces (i.e., mimetic, normative, or coercive) drive actors to become similar to one another through the adoption of similar practices and activities (DiMaggio \& Powell, 1991, pp. 65-66). Although this perspective helps explain homogenization and institutional stability, several scholars criticize this approach for failing to explain how actors actively participate in changing institutions.

In response, many neo-institutional theorists advocate a political or strategic approach to institutions (DiMaggio, 1988, p. 14; Seo \& Creed, 2002, p. 222). A political approach to institutions conceptualizes actors as institutional entrepreneurs. Institutional entrepreneurs use social skills such as language to shape the institutional logics that legitimate a given field (Clemens \& Cook, 1999; Fligstein, 1997, 2001; Suddaby \& Greenwood, 2005). Institutional logics are the belief systems that guide actions in an organizational field (Friedland \& Alford, 1991; Rao, 2003; Scott, 2001). Institutional logics also provide the criteria of legitimacy for the formation and reproduction of specific identities, practices, and social relationships within a given field (Greenwood \& Hinings, 1996; Scott, 2001; Suddaby \& Greenwood, 2005).

Although the dominant institutional logic of a field is often implicit or taken for granted and is thus unavailable for conscious manipulation and choice (Dobbin, 1994), most fields are heterogeneous, containing multiple institutional logics that sometimes are in conflict with one another (Friedland \& Alford, 1991; Seo \& Creed, 2002; Thornton \& Ocasio, 1999). Within this framework, fields are political arenas in which actors or institutional entrepreneurs pursuing a variety of differing interests pit logics against each other to achieve dominance (Boxenbaum \& Battilana, 2005).

\section{A Rhetorical View of Institutions}

We argue that rhetoric is an important social skill used by institutional entrepreneurs in the construction and competition of institutional logics. Rhetoric is "discourse calculated to influence an audience toward some end" (Gill \& Whedbee, 1997, p. 157). Through rhetoric, actors produce and assign meaning, constructing both their identities and the world (Bitzer, 1968; Booth, 1974; Burke, 1969; Perelman \& Olbrechts-Tyteca, 1969). 
A rhetorical view of institutions assumes that institutions are simultaneously material and symbolic (Green, 2004). As the material practices of institutions spread and diffuse, they are accompanied and supported by symbolic justifications that make sense and legitimate the appropriateness and effectiveness of particular social practices and structures (Berger \& Luckmann, 1966). A rhetorical view of institutions emphasizes how rhetorical strategies shape the persuasiveness of practices to potential adopters and institutional adherents (Green, 2004; Suddaby \& Greenwood, 2005). Actors shape institutional fields by making persuasive arguments that justify, rationalize, and legitimate institutional logics and/or criticize and delegitimate competing logics (Green, 2004).

\section{Rhetorical Strategies and the Production of Legitimacy}

Although the field of rhetoric is replete with rhetorical strategies capable of shaping the legitimacy of institutional logics, scholars working at the intersection of rhetoric and institutions emphasize the importance of three rhetorical strategies or appeals: pathos, logos, and ethos (Green, 2004). Pathos describes appeals to emotion. Logos describes appeals to logic, and ethos describes appeals to speaker credibility, moral authority, or tradition (Green, 2004; Nohria \& Harrington, 1994). Whereas pathos and logos strategies appeal to an audience's self-interest and shape pragmatic legitimacy, ethos strategies appeal to normative approval and moral propriety and produce moral legitimacy (Green, 2004; Suchman, 1995, pp. 578-579, 584-585). In addition, the rhetorical strategies of pathos, logos, and ethos are theorized to produce cognitive legitimacy: comprehension followed by taken-for-grantedness (Green, 2004). Within this framework, rhetoric plays an important role in the institutionalization process because rhetoric shapes the legitimization and delegitimization of practices and structures within an institutional field.

\section{Data and Method}

\section{Rhetoric and the Competition Between the Institutional Logics of Corporate Control}

To illustrate how rhetoric shapes the competition of institutional logics within an institutional field, we examine changes in corporate control and corporate control rhetoric as a case study. The modern corporation is a 
broad and complex institutional field with many material and symbolic referents in corporate practices, governance systems, and laws. We limit the scope of our project by focusing on changes in corporate control from 1978 to 1998. Several scholars note that this was a period of tremendous competition between corporate institutional logics as well as changes in the corporate institutional field (Davis, 2005; Hirsch, 1986; Useem, 1993). Scholars suggest that the corporate institutional field was dominated by two major competing institutional logics (Useem, 1996). The first institutional logic, labeled here Managerial Capitalism (MC), suggests that managers should have control of the firm because they have superior knowledge to do so efficiently and effectively. Here, the emphasis is on ensuring that those who are most qualified to run the firm have the power and authority to make relevant business decisions. This institutional logic legitimizes the authority of managers and advocates their control over the firm (Chandler, 1977; Useem, 1993). The second institutional logic, labeled here Investor Capitalism (IC), asserts that managers are simply agents of their firms' shareholders and must be made to run the firm in the shareholders' best interests (Jensen \& Meckling, 1976; Useem, 1996). This logic emphasizes shareholder value maximization. It suggests managerial power must be checked, and potentially limited, to protect shareholders. This institutional logic legitimizes the authority of the shareholders and advocates their control over the corporation. Together, the logics of MC and IC advocate alternative and competing institutional arrangements of authority and practice within the corporate institutional field.

\section{Data Collection and Organization}

To examine the rhetoric shaping the logics or belief systems of MC and IC, we trace corporate control arguments in interviews with corporate board members from 1978 to 1998 . To understand how institutional logics shaped the corporate institutional field, we analyze the diffusion of takeovers and takeover defenses.

\section{Business/Legal Articles: Reconstructing the Argumentative Context}

Before conducting our interviews, we immersed ourselves in the language and rhetoric of IC and MC. Specifically, we collected a total of 477 articles about corporate control from business and legal publications sources from 1978 to 1998. Some of the sources included The Wall Street 
Journal, Business Week, Nation's Business, The Economist, Industry Week, Harvard Business Review, U.S. News \& World Report, Financial Times, The New York Times, Fortune, Financial World, Barrons', and Harvard Law Review. We also conducted extensive readings in the larger academic literature on corporate control. The coauthors read and discussed these articles to develop a comfort level with the rhetoric of IC and MC. Although our coding and results were conducted solely on the interview data, the articles and literature review provided a robust framework for helping us understand how to reconstruct the argumentative context or specific appeals used to justify or criticize IC and MC logic from the interview data.

\section{Training the Coders to Identify Rhetorical Strategies}

The business and legal news articles were used to help train the coders to identify rhetorical strategies in corporate control arguments. Two part-time research assistants were hired for 15 one-hour training sessions. During the training sessions, the definition, context, and history of IC and MC were discussed. The discussion of IC and MC was followed by a discussion of pathos, logos, and ethos. Each research assistant then practiced identifying these appeals in randomly sampled business/legal articles. The practice sessions were followed by several informal and formal tests. The informal test consisted of separately coding five randomly sampled articles about corporate control. Differences and similarities in coding among the research assistants' identifications of rhetorical strategies were discussed and evaluated. Five informal tests were conducted. The first test had roughly $65 \%$ accuracy improving progressively to $85 \%$ accuracy for the last test. In conducting the formal test, the research assistants were given five randomly sampled news articles-15 in all. Data were coded separately. Thirteen out of 15 were perfect matches. The discrepancies were discussed. The main discrepancy consisted of research assistants sometimes coding descriptions as justifications. The coded data were put aside, and 15 more examples were resampled. Fourteen out of 15 were perfect matches. Each of the discrepancies was reviewed and checked for systematic bias. No systematic bias was found. After consistently achieving $90 \%$ or better coding accuracy, the 71 interviews were randomly assigned to each coder so that each received approximately the same number of interviews for each period. Our results and findings in this study are from the interviews and not from the news articles. The news articles were used only to increase the authors' and coders' familiarity with the corporate control rhetoric, as well as our ability to recognize specific rhetorical arguments and appeals in the interview text. 


\section{Collecting the Interviews}

Phone and in-person interviews were conducted by Green while attending Harvard Business School. The transcribed interviews provide a detailed and valid understanding of the rhetoric used to support the logics of IC and MC. Scholars have theorized that interviews are an excellent tool for acquiring knowledge of what people believe or think and how their thoughts shape their behavior (Singleton, Straits, \& Straits, 1993, p. 322). Ninety companies were randomly sampled from the Standard \& Poor's (S\&P) 1500 and contacted for telephone and in-person interviews. Seventy-one companies responded, and the authors conducted 12 in-person interviews and 59 phone interviews. The in-person interviews were approximately 1 hour in length, and the phone interviews were approximately 45 minutes in length.

To focus the interviews, decrease memory bias, and highlight the competition between the IC logic and MC logic, respondents were asked to focus on a specific corporate control event. There are many corporate control events. We chose to focus on the decision to adopt a takeover defense. The decision to adopt a takeover defense emphasizes the question of who should control the corporation. Respondents were asked several questionsfor example, when they adopted a particular defense, why they adopted a takeover defense, in whose interest the firm should be run, and who should control the firm.

Major corporate control decisions are made during board meetings by board members. The interviewees were present at these board meetings. They were lawyers, board members, and/or corporate secretaries. All of the interviewees had extensive familiarity with important corporate control issues and events within the firm. Usually, the firm's advisers (investment bankers, lawyers, consultants, or board members) argue for or against a specific corporate control practice such as a takeover defense. For the successful adoption of corporate control practices and procedures, participants of the board meeting must legitimate or ground this act in a set of logics, values, and definitions that are persuasive to the majority of board members. The interviews show how boards rhetorically construct and support the IC logic or MC logic when choosing to adopt or not adopt a takeover defense. For example, the interviews illustrate what types of arguments are used to legitimize (or de-legitimize) a takeover defense, what types of arguments are used to rhetorically support an IC logic or an MC logic, and what types of arguments directors find more or less persuasive. 


\section{Analysis of Interviews}

The trained coders coded the interviews for major themes, arguments, and rhetorical appeals. The arguments and themes were organized in terms of three major dimensions. The first dimension was pathos, logos, and ethos; the second dimension was pro-IC logic or pro-MC logic; and the last dimension was time relative to our research period: early, middle, late. The first dimensions of pathos, logos, and ethos were chosen because these appeals are the most basic and fundamental rhetorical appeals (Aristotle, 1991). This choice allows us to show how basic rhetorical appeals shape institutional logics and provides a framework for adding additional and perhaps more specialized rhetorical appeals in future research. In most social situations, pure pathos, pure logos, or pure ethos arguments are relatively rare compared to arguments that are made up of combinations of appeals. Corporate control arguments are no exception and are also more complex in the real world. Coders coded the number of times a rhetorical appeal appeared in an argument regardless of whether it was combined with another appeal.

The second dimension of pro-IC logic or pro-MC logic highlights the rhetorical contestability of institutional logics as they compete for domination over the institutional field. Finally, the third dimension of time organizes the data into three separate time periods of early, 1978 to 1984; middle, 1985 to 1991; and late, 1992 to 1996. We grouped the data into three periods to emphasize how changes in the institutional field and the institutionalization process move from periods of flux and instability to periods of order and stability.

\section{Changes in Corporate Control: Institutional Field Dynamics}

There are several ways to measure changes in control over the corporate institutional field. We chose to examine several well-recognized measures to describe how corporate institutional field arrangements changed from 1978 to 1998. The measures we look at are takeover and takeover defenses. Changes in takeover and takeover defenses show the actual oscillation of power and control between managers and shareholders, the two most powerful stakeholder groups within the firm. The purpose of our analysis is to link changes in the arrangement of the corporate institutional field or corporate control to the competition of logics and underlying rhetorical appeals put forth by various corporate stakeholders vying for control over the corporation. 
In the following section, we first describe the conditions and context that allowed for the development of MC and IC. Second, we detail how rhetoric shaped MC logic and IC logic, commenting on the material effects of these changes on the corporate institutional field. We conclude our analysis with a discussion of theoretical and practical implications.

\section{Data Analysis and Results Section}

\section{A Brief Overview of Corporate Control}

Prior to the early 20th century, families privately owned and controlled the great American companies. Families provided the capital, organizational knowledge, and technical skills required to run their companies efficiently. Needless to say, their contributions created a corporate governance system where their authority and control were unchallenged within the economic enterprise (Bendix, 1963, p. 267; Perrow, 1993, p. 56). At the turn of the century, the fast-paced industrial expansion placed pressure on families to keep up with the ever-increasing capital, organizational, and technical needs. Ultimately, these needs began to outstrip the resources and capabilities of their owners (Bendix, 1963; Chandler, 1977). Successful enterprises adapted by acquiring capital from the securities markets and by hiring professional managers with the skills and knowledge to cope with the complexities brought on by the larger scale.

Although acquiring capital from the securities markets and hiring professional managers to run the corporation allowed firms to grow more successfully, it also dispersed the shareholder base and left the corporation's owners unable to assert their will collectively (Berle \& Means, 1991; Chandler, 1977; Roe, 1994). A fragmented shareholder base, coupled with a shift in decision-making power from owners to managers, produced a corporate form dominated and controlled by the visible hand of the manager (Berle \& Means, 1991; Chandler, 1977).

For much of the 20th century, MC was an efficient and stable corporate field arrangement (Chandler, 1977). However, separating ownership from control created new tensions and problems of corporate governance. Although professional, nonowning managers successfully solved the corporation's problems, shareholders found it difficult to ensure that managers solved problems in a way that best served their interests. Professional management brought with it considerations of career, power, and other personal motives that sometimes were in conflict with the owner's interests (Fama, 1980; Jensen \& Meckling, 1976; Shleifer \& Vishny, 1986). 
At its core, the separation between ownership and control gives rise to the question: Whose firm is it? Legally, managers and board members are fiduciaries of the corporation. As fiduciaries of the corporations, managers and board members are responsible to the corporation as a whole as opposed to any one group such as shareholders. This legal mandate leaves unresolved many questions regarding the appropriate goals and means of the corporation (Blair, 1995; Lorsch, 1989). Three rhetorics developed out of this ambiguity: (a) proshareholder rhetoric, (b) promanagerial rhetoric, and (c) prostakeholder rhetoric (Blair, 1995). Proshareholder rhetoric asserts that the appropriate goals and actions of the corporation are to maximize shareholder value. This rhetoric supports IC logic and often criticizes MC logic. Promanagerial rhetoric often acknowledges the importance of maximizing shareholder value but questions the best means for achieving this goal. This rhetoric supports MC logic and often criticizes IC logic. Prostakeholder rhetoric argues that the goal of the corporation is to maximize society's value as opposed to shareholder value. This rhetoric can potentially support or criticize either MC logic or IC logic, but it is often allied with managerial rhetoric to support MC logic. These three rhetorics are used by corporate stakeholders to shape the competition between corporate institutional logics and thus influence which stakeholders control the corporate institutional field.

\section{Takeovers and the Battle for Corporate Control}

Unable to control management through the proxy process, owners dissatisfied with management's performance initially followed the "Wall Street Rule," silently exiting a firm's ownership structure by selling their shares and moving on (Hirschman, 1970; Useem, 1993, p. 19). However, by the 1950s, shareholders had discovered a new way to show dissatisfaction with management's performances-by forcibly changing control of the firm, a tactic that came to be called the "hostile takeover" (Hirsch, 1986, p. 806). Hostile takeovers are tender offers made without the approval of a target's board (Davis \& Stout, 1992, p. 607). Management scholars argue that hostile takeovers result from poor managerial performance, driving a firm's stock price so low that more competent outsiders believed they can take control and drive the firm's value back up (Manne, 1965).

Before the 1970s, the hostile takeover was perceived as illegitimate and therefore not widely used (Hirsch, 1986, p. 808). However, a significant decline in American industrial performance in the 1970s created an impetus for a large and powerful takeover wave in the 1980s that challenged the 


\section{Figure 1}

Takeover Attempts per Year for U.S. Firms

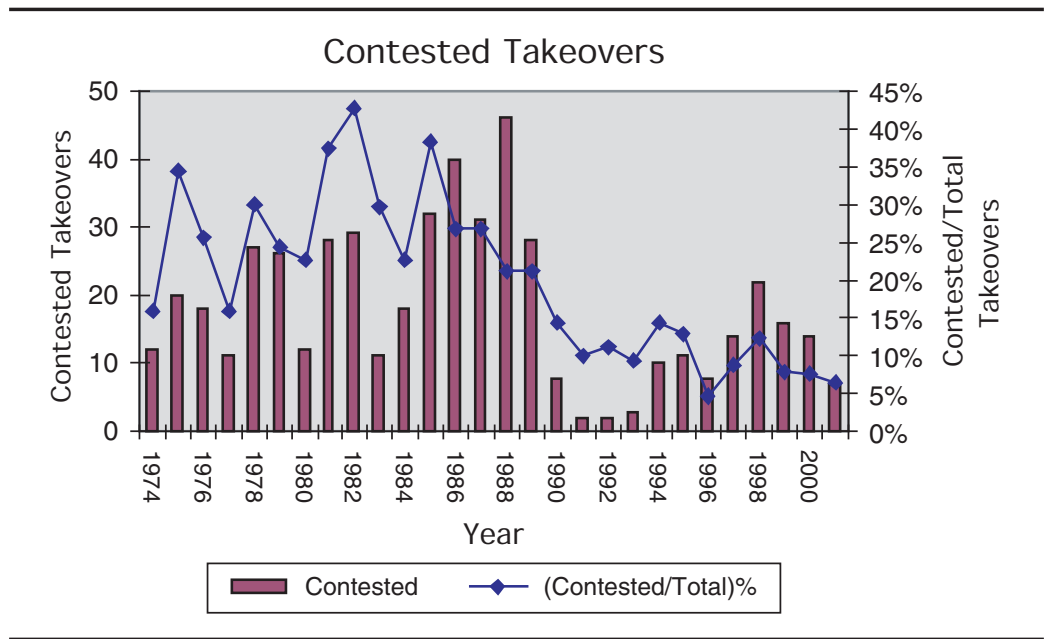

Source: Based on data from MergerStat (2004).

Note: MergerStat is a research company that publishes U.S. merger and acquisitions information.

dominance of the MC logic and managerial control of the corporate institutional field. The decline in performance raised questions for the larger society regarding managerial autonomy and stewardship of large corporations. In addition, a decline in equity values combined with cheap and plentiful debt provided a unique and tremendous opportunity for takeover entrepreneurs to seize control of underperforming firms (Baker \& Smith, 1998).

The adherents and creators of the IC logic used these conditions to rhetorically strengthen the legitimacy of corporate takeovers (Drucker, 1991, p. 109; Jensen, 1989, p. 65; Useem, 1993, p. 20), encouraging the deregulation of takeovers and the gutting of antitrust enforcement, which facilitated the creation of an active market for corporate control (Davis \& Stout, 1992, p. 607). By the end of the 1980s, nearly one third of the largest publicly traded corporations in the United States had been subject to a takeover attempt (Faltermeyer, 1991). And by 1988, almost $10 \%$ of the 1980 Fortune 500 had been acquired in transactions that started as hostile and resulted in a hostile takeover, an escape to a white knight, ${ }^{1}$ or a management buyout $^{2}$ (Shleifer \& Vishny, 1986). Figure 1 shows the total number of takeover attempts per year for U.S. firms. 


\section{The Managerial Response to the Takeover Wave}

The development of a market for corporate control set the values of owners (e.g., appreciation and return on investment) against those of management (e.g., managerial autonomy, security, status, and orderly career paths) as well as broad constituents (e.g., stability and low risk of bankruptcy) (Coffee, 1986; Hirsch, 1986; Shleifer \& Summers, 1988; Tillman, 1989). Prior to the takeover wave of the 1980s, managers and shareholders had seldom been placed in a setting of formal conflict (Fama, 1980; Hirsch, 1986; Jensen \& Meckling, 1976).

The rise and diffusion of hostile takeovers in the late 1970s and 1980s harmed managers (Useem, 1993). Managers lost power, prestige, and job security (Hirsch, 1986). Managers were not the only group adversely affected by the takeover wave of the 1980s. Other constituents such as employees, bondholders, communities, and so on were also affected. Employees were laid off, bondholders faced higher levels of risk, and communities faced plant closings (Blair, 1995; Shleifer \& Summers, 1988). Managers of most large corporations responded to the takeover wave by allying themselves with other constituents: minority shareholders, employees, the board, and larger society. They lobbied the larger society to create regulations and impediments against hostile takeovers as well as adopted firm-specific takeover defenses that made it more difficult for outsiders to take over the firm without management's consent. Some takeover defenses limited shareholder voice in the firm (e.g., by limiting written consent, special meetings, and supermajority provisions), some enhanced board power (e.g., blank check preferred, poison pills, and classified boards), whereas others protected broad constituent claims (e.g., fair price provisions, golden parachutes, and Employee Stock Ownerships Plans (ESOPs; Green, 2001). Figure 2 shows the adoption of takeover defenses across the SP 1500 from 1975 to 1998.

\section{Using Rhetoric to Support or Criticize IC and MC Logics}

IC logic advocates the use of takeovers, and MC logic promotes the use of takeover defenses. When takeovers and takeover defenses are adopted at firms, certain corporate actors gain or lose power in relation to other social actors. These actors do not sit by idly as their interests are affected; they compete with each other for power over the process and outcome (Enteman, 1989). These actors use rhetoric to unite members of a group to defend their interests against opposing groups (Bendix, 1963, p. 199). They also use rhetoric to form broader coalitions, construct common interests, garner 


\section{Figure 2}

\section{Takeover Defense Diffusion}

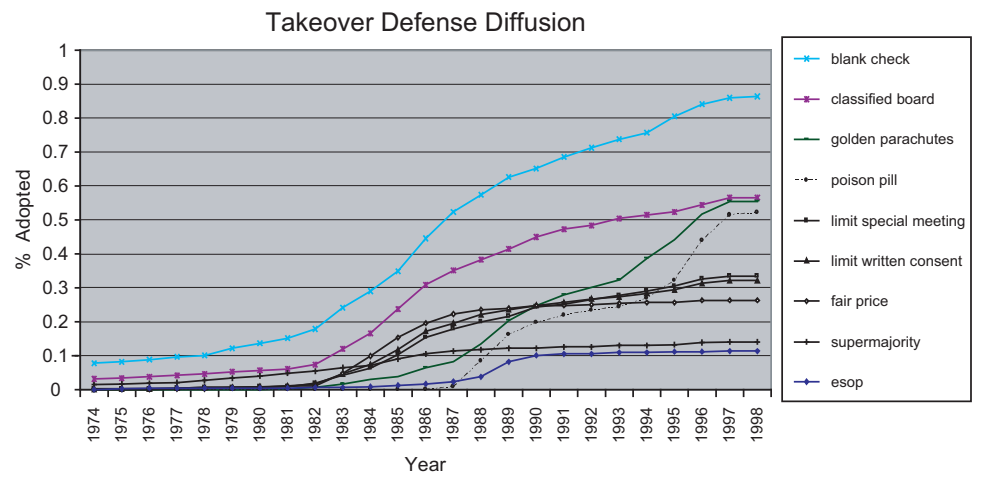

Source: These data were collected from the Investor Responsibility Research Center (IRRC). Every year, the IRRC scans proxies and Securities \& Exchange Commission filings to ascertain the date of adoption of takeover defenses (Rosenbaum, 1998).

resources, and define problems and appropriate solutions (Davis \& Thompson, 1994; Geertz, 1973; Granovetter, 1985; Snow \& Benford, 1992; Snow, Rochford, Worden, \& Benford, 1986).

Managers use rhetoric to persuade shareholders, board members, and other constituents that MC logic and the takeover defenses the logic advocates are in their interests and not just devices intended to benefit and entrench management. In contrast, shareholders used rhetoric to convince broad stakeholders as well as the larger society that IC logic and the takeovers this logic promotes are in the best interests of shareholders, broad constituents, and society at large. Tables 1 and 2 summarize our results. They show how the various stakeholder groups used rhetoric to support or criticize IC logic and MC logic from 1978 to 1998.

Table 1 summarizes the coding results for all 71 interviews. The table shows each of the three periods: early, middle, and late in the research process. The table also shows the number of interviews coded by either Coder 1 or Coder 2. There are six coding criteria ranging from MC-Pathos or pro-MC pathos argument to IC-Logos or pro-IC logos argument. The results also display the average number and type of argument per interview, the standard deviation of that type of argument across the interviews, as well as the total number of arguments in all of the interviews. For example, in the early period, Coder 1 coded 12 interviews and found a total of 28 pro-MC 


\section{Table 1}

\section{Coding Results}

\begin{tabular}{|c|c|c|c|c|c|c|c|}
\hline \multirow[t]{10}{*}{ Early Period } & Coder 1 & 12 interviews & & & & & \\
\hline & Logic-Rhetoric & MC-Pathos & MC-Logos & MC-Ethos & IC-Pathos & IC-Logos & IC-Logos \\
\hline & Average & 2.33 & 1.92 & 1.08 & 1.25 & 0.42 & 0.25 \\
\hline & $S D$ & 1.83 & 1.38 & 1.16 & 0.87 & 0.67 & 0.45 \\
\hline & Total & 28 & 23 & 13 & 15 & 5 & 3 \\
\hline & Coder 2 & 12 interviews & & & & & \\
\hline & Logic-Rhetoric & MC-Pathos & MC-Logos & MC-Ethos & IC-Pathos & IC-Logos & IC-Logos \\
\hline & Average & 3.50 & 1.67 & 0.50 & 1.25 & 0.67 & 0.92 \\
\hline & $S D$ & 1.09 & 0.98 & 0.52 & 0.62 & 0.89 & 0.29 \\
\hline & Total & 42 & 20 & 6 & 15 & 8 & 11 \\
\hline \multirow[t]{10}{*}{ Middle Period } & Coder 1 & 14 interviews & & & & & \\
\hline & Logic-Rhetoric & MC-Pathos & MC-Logos & MC-Ethos & IC-Pathos & IC-Logos & IC-Logos \\
\hline & Average & 1.21 & 1.57 & 1.07 & 0.71 & 1.71 & 0.86 \\
\hline & $S D$ & 0.89 & 0.76 & 0.73 & 0.47 & 1.07 & 0.95 \\
\hline & Total & 17 & 22 & 15 & 10 & 24 & 12 \\
\hline & Coder 2 & 13 interviews & & & & & \\
\hline & Logic-Rhetoric & MC-Pathos & MC-Logos & MC-Ethos & IC-Pathos & IC-Logos & IC-Logos \\
\hline & Average & 1.31 & 1.92 & 1.38 & 1.15 & 2.15 & 0.77 \\
\hline & $S D$ & 1.12 & 1.44 & 1.04 & 0.80 & 0.99 & 0.73 \\
\hline & Total & 17 & 25 & 18 & 15 & 28 & 10 \\
\hline \multirow[t]{10}{*}{ Late Period } & Coder 1 & 10 interviews & & & & & \\
\hline & Logic-Rhetoric & MC-Pathos & MC-Logos & MC-Ethos & IC-Pathos & IC-Logos & IC-Ethos \\
\hline & Average & 0.30 & 2.00 & 2.80 & 0.70 & 1.30 & 2.00 \\
\hline & $S D$ & 0.48 & 1.33 & 1.55 & 0.67 & 1.06 & 1.05 \\
\hline & Total & 3 & 20 & 28 & 7 & 13 & 20 \\
\hline & Coder 2 & 10 interviews & & & & & \\
\hline & Logic-Rhetoric & MC-Pathos & MC-Logos & MC-Ethos & IC-Pathos & IC-Logos & IC-Ethos \\
\hline & Average & 0.40 & 1.80 & 2.60 & 1.00 & 2.00 & 2.20 \\
\hline & $S D$ & 0.52 & 1.03 & 0.97 & 0.67 & 1.32 & 1.75 \\
\hline & Total & 4 & 18 & 26 & 10 & 20 & 22 \\
\hline
\end{tabular}

Note: Labeled cells: Coder 1 and Coder 2 for both logics found a greater number of pathos arguments in the early period, logos arguments in the middle period, and ethos arguments in the last period. $\mathrm{MC}=$ managerial capitalism; IC = investor capitalism.

arguments that used pathos. Within the set of 12 interviews coded by Coder 1 , the average number of arguments found in each interview was 2.33 with a standard deviation of 1.83 . The results show that for both logics, Coder 1 and Coder 2 found for a greater number of pathos arguments in the early period, logos arguments in the middle period, and ethos arguments in the 
Table 2

The Evolving Rhetoric of Corporate Control

\begin{tabular}{|c|c|c|c|}
\hline Time Period & Logic & Rhetoric & Primary Actor \\
\hline \multirow[t]{2}{*}{ 1978-1984 } & $\mathrm{MC}$ & Pathos_-"barbarians at the gate" & Professional managers \\
\hline & IC & $\begin{array}{l}\text { Pathos-"managerial greed } \\
\text { and industrial decline" }\end{array}$ & $\begin{array}{l}\text { Shareholders-takeover } \\
\text { entrepreneurs }\end{array}$ \\
\hline \multirow[t]{2}{*}{ 1985-1991 } & $\mathrm{MC}$ & $\begin{array}{l}\text { Logos_-"efficiency and managerial } \\
\text { expertise/knowledge" }\end{array}$ & Professional managers \\
\hline & IC & $\begin{array}{l}\text { Logos-"efficiency and the } \\
\text { market for corporate control" }\end{array}$ & $\begin{array}{l}\text { Shareholders-financial } \\
\text { economists }\end{array}$ \\
\hline \multirow[t]{2}{*}{ 1992-1998 } & $\mathrm{MC}$ & $\begin{array}{l}\text { Ethos-"broken promises and } \\
\text { residual claimants" }\end{array}$ & $\begin{array}{l}\text { Managers and broad } \\
\text { constituents }\end{array}$ \\
\hline & IC & $\begin{array}{l}\text { Ethos_-"shareholder democracy } \\
\text { and property rights" }\end{array}$ & $\begin{array}{l}\text { Shareholders-share } \\
\text { holder activists }\end{array}$ \\
\hline
\end{tabular}

Note: $\mathrm{MC}=$ managerial capitalism; $\mathrm{IC}=$ investor capitalism.

last period (see the shaded cells in Table 1). A key point is that both coders found that pathos appeals dominated in the early period, logos appeals in the middle period, and ethos in the last period.

Table 2 summarizes and describes our previous findings. The first column of Table 2 shows the three historical time periods under analysis. The second column shows the two types of logics for each time period. The third column shows the type of rhetoric and logic for each period and provides a short description of the overall argument for that period. The fourth column shows the primary actors in each time period as well as the logic they promoted. Our basic interpretation of the results suggests that the institutional logics of MC and IC moved through a rhetorical sequence of pathos in the early period, logos in middle period, and ethos in the last period.

In the following sections we provide specific examples of the rhetoric contained in the interviews. We also describe the historical and cultural context in which these rhetorical arguments were constructed and interpreted by broad stakeholders, managers, and shareholders.

\section{Examples of Interview Rhetoric}

\section{Barbarians at the Gate: MC Logic and Pathos Arguments (1978-1984)}

From 1978 to 1984, the corporate institutional field began to change as hostile takeovers spread to large corporations (see Figure 1). In response, 
many boards of directors were faced with the decision to adopt or not to adopt takeover defenses. At this time, the dominant rhetorical appeal supporting the adoption of takeover defenses and supporting MC logic used pathos and argued that hostile acquires were "barbarians at the gate" coming into the firm to rape and pillage. An example of this rhetoric collected from the interviews illustrates the rhetorical appeal:

We adopted takeover defenses because of the KKRs ${ }^{3}$ of the world. They were pirates stealing companies and laying off workers. Most of these guys were coming in to make a fast buck, and they took over some companies that really didn't need to be taken over. They put the fear of God into the CEO and our board. But it wasn't just the raiders that did it. It was also the institutional investors screaming and the overall economic malaise. We were afraid, and we adopted takeover defenses to protect ourselves in order to remain independent.

This statement, coded as pathos, is representative of the rhetoric supporting MC logic from 1978 to 1984. During this period, managers faced the rhetorical task of rallying allies to the importance and threat of the takeover wave. Managerial rhetoric argued that the firm was threatened by barbarians waiting to pillage and rape the firm. The majority of appeals in support of $\mathrm{MC}$ logic were pathos during this period. These pathos appeals garnered the attention and support of board members, employees, local communities, and state legislatures.

Pathos arguments also helped to ideologically unify the managerial class. In the early stages of the takeover wave, managers had differing opinions about the use of takeover defenses. Some managers wanted the ability to initiate takeovers, yet they also wanted the ability to protect their firms from hostile acquisitions (Haunschild, 1993). In 1988, the Business Roundtable argued that takeovers hurt the U.S. economy; however, from 1985 to 1988 , more than $75 \%$ of its membership initiated takeovers of other firms (Davis \& Thompson, 1994). As an argumentative technique, pathos appeals were perfect for dealing with this hypocrisy. Pathos or emotional appeals help suspend both the audience and speaker's ability to recognize contradictions. Pathos arguments elicit instinctive reactions (e.g., fear, passion, and competitiveness) as opposed to thorough and thoughtful analysis of situations. The use of pathos appeals allowed the management of firms like AT\&T simultaneously to conduct takeovers (e.g., the acquisition of the National Cash Register Company [NCR]) and then tell their board, shareholders, and employees that hostile acquisitions were a grave threat to corporate interests. 
In addition, many takeover practices in the early period were coercive and thus easy targets for the construction of critical pathos arguments. The image of pirates, raiders, and barbarians easily resonated with the speed and hostility of many of these transactions (Hirsch, 1986). Managers used the coercive two-tier tender offers as well as other requests to sell the firm as opportunities to show board members that their responsibility was to the long-term shareholder. Managers pitted one group of shareholders against another by describing the two-tier bid as an attempt by takeover entrepreneurs to enrich themselves at the expense of long-term shareholders. Two-tier bids were also described as coercing board members and management to sell the firm at prices far below the long-term value of the firm.

Another pathos argument accused shareholders of having time horizons too short to maximize effectively the long-run value of the firm (Blair, 1995, p. 144-146; Porter, 1997). This rhetorical suggestion highlighted the difference between different sets of shareholders: long-term shareholders versus short-term arbitrageurs. It also attempted to explain why American industry was underperforming international competitors such as Japan and Germany. Specifically, managers argued that recent underperformance was a direct cause of managers' having to appease the short-term requirements of capital markets, whereas international competitors established long-term competitive advantages. The pathos of this argument highlighted both the greed of short-term stockholders and the fear of American industrial decline and obsolescence vis-à-vis international competitors (Blair, 1995, pp. 124; 144-146, Porter, 1997; Useem, 1993).

Finally, pathos rhetoric helped to merge the managerial and broad stakeholder interests by creating an ideology of "us" versus "them." This argumentative move was the first attempt by either managers or shareholders to align broad stakeholder rhetoric with MC logic or IC logic. Managers' pathos rhetoric emphasized that takeover entrepreneurs were intent on instigating massive layoffs, breaking up firms, and destroying the economic livelihood of communities. Bondholders and the general financial community were told that takeovers were overleveraging America for the benefit of a few self-interested and greedy takeover entrepreneurs. Employees were told that takeovers would cost them their jobs and ability to feed their families. These arguments helped unite the managerial and broad stakeholder rhetoric behind MC logic and the adoption of takeover defenses. 


\section{IC Logic and Managerial Greed Declining American Industrial Performance Pathos Arguments (1978-1984)}

Managerial rhetoric did not appear in a vacuum. In many respects, the rhetoric promoting takeover defense adoption was a reaction to rhetoric promoting the use of takeovers. The positive rhetoric of takeovers and corresponding negative rhetoric against takeover defense adoption developed out of the shareholder rhetoric. Shareholder rhetoric suggests that takeovers are a legitimate means of disciplining management, and takeover defenses are seen as an illegitimate intrusion into the principal-agent relationship.

Similar to the dominant rhetorical appeal supporting the adoption of takeover defenses and supporting MC logic, the dominant rhetoric criticizing the adoption of takeover defenses and supporting IC logic used pathos from 1978 to 1984 . As illustrated in the following example collected from the interviews,

Our institutional shareholders thought managers were just greedy and wasteful and takeover defenses were tools to prolong their entrenchment. They thought takeover defenses were a throwback to the days when CEOs ran companies in their interests and boards just rubber-stamped policies.

Shareholders argued that society's economic health was dependent on shareholder control of the firm. The industrial decline of the 1970s provided shareholders a unique opportunity to rhetorically attack managerial control of the firm. Rhetorically, shareholders seized this opportunity to reassert the primacy of their rights by questioning the legitimacy of managerial corporate hegemony. Simply put, if managers were the rightful stewards of the American firm, why was the economy falling apart? Allies and proponents of the IC logic answered these questions by suggesting that the rightful stewards were the shareholders.

Perhaps the first voices to espouse this rhetoric were takeover entrepreneurs like Carl Icahn and T. Boone Pickens. They linked America's industrial decline to managerial waste and inefficiency, arguing that managerial greed and empire building were at the root of America's economic woes (Icahn, 1988). These pathos arguments were combined with other fear-based appeals that emphasized the growing obsolescence of American business in face of Japanese and foreign competition. Using these arguments, takeover entrepreneurs became to shareholders what labor organizers were for labor (Enteman, 1989, p. 243), building organizations, rallying support, and galvanizing allies. The exhortations of takeover entrepreneurs did not fall on deaf ears. Institutional 
shareholders such as Jesse Unruh, the treasurer of California, used this rhetoric to organize public pension funds to promote takeovers and criticize the use of takeover defenses (Monks \& Minow, 1991, p. 213).

The majority of arguments during this period were dominated by pathos. Questioning the legitimacy of managerial control and advocating shareholder control was not an easy task. Managerial control was the status quo, supported by the enormous social inertia of social habit and social custom. Yet pathos is an excellent rhetorical tool for overcoming the inertia of the status quo. Pathos elicits the instinctive reactions of fight or flight. Pathos, more than ethos or logos, has the ability to grab the audience's attention and short-term willingness to act (Green, 2004).

\section{Logic and the Superior Knowledge of Managers' Logos Arguments (1985-1991)}

In the middle of the research period, the dominant rhetorical appeal in support of takeover defenses and the MC logic was logos. An example of this rhetoric collected from the interviews follows:

Takeover defenses give the board time to fulfill its fiduciary responsibility. The law places the board in control because they have the knowledge and information to make the best decisions for the firm. There are so many issues and factors to consider, and without takeover defenses, the people with the expertise can't do their job. Only through advance preparation and thorough analysis can a board really act in the best interests of shareholders.

This statement, coded a logos, represents a set of important logos arguments used to support takeover defense adoption in the middle period. This rhetoric supported and extended the power of earlier pathos arguments. Logos arguments were built on assumptions regarding the relationships between knowledge, risk, and control. The basic assumptions were that increases in knowledge or risk should accompany increases in control. These assumptions were highly institutionalized and provided immense rhetorical power to those who could effectively leverage them.

For example, the classic argument of managerial control suggested that managers were given control of the firm because their superior knowledge and expertise increased corporate efficiency and effectiveness (Berle \& Means, 1991; Chandler, 1977; Useem, 1993). Externally, knowledge justifies managerial control of the firm because superior managerial knowledge is assumed to benefit larger society. Within the firm, managerial control is 
legitimated by the belief that one's superiors have more knowledge (technical competence) and that this knowledge will benefit both the superior and the subordinate (Perrow, 1993). Although this rhetorical logic is initially benign, embedded within the logic are the seeds of a powerful rhetorical dynamic. Specifically, if the legitimacy of authority is predicated on having superior knowledge, then increases in knowledge increase the legitimacy of authority. Yet the very nature of managerial control presupposes an accumulation and acquisition of knowledge by managers (Taylor, 1911). Simply put, managers argue for control of the firm because they have superior knowledge, which increases their authority to accumulate even more knowledge. This rhetorical dynamic produces a self-reinforcing system of legitimacy and control of tremendous stability and power. In fact, this rhetorical structure is so powerful that perhaps only the major industrial decline of the 1970s was capable of dismantling managerial control of the firm (Blair, 1995, pp. 211-220; Votaw, 1965).

The managerial rhetoric of superior knowledge reverberates throughout society and manifests itself most powerfully within the courts. For example, when deliberating over the appropriateness of managerial actions and decisions, the courts usually rely on the business judgment rule (Bainbridge, 2004). The business judgment rule assumes that managerial knowledge is superior to all other types of knowledge about the firm, thus routinely subjecting a manager's decisions to judicial scrutiny would probably cost society more in the long run than tolerating some bad judgments and minor malfeasance. The courts are usually very reluctant to second-guess boards or management unless gross negligence or self-dealing is involved in the decision or action being challenged (Blair, 1995, p. 60; Weston, Chung, \& Siu, 1990). In short, managers are the most efficient stewards of the firm, and thus takeover defenses should be adopted to provide them with the time and autonomy to run the firm with the skills and expertise that only they have.

\section{IC Logic and the Efficiency of an Active Market for Corporate Control Logos Arguments (1985-1991)}

From 1985 to 1991, the dominant rhetorical appeal criticizing takeover defenses and supporting IC logic was logos. The following example, coded as $\log$ os, illustrates this rhetoric:

Representatives of institutional investors are usually adamantly opposed to takeover defenses. They will cite several studies by academics and the SEC 
showing that takeover defenses decrease shareholder value. The percent declines are small but they are still significant for our large shareholders. These studies make it more difficult for us to adopt them.

In the early period, shareholders blamed the decline in American industrial performance on managerial control. When confronted with a rhetorical attack on their legitimacy and accusations of their poor performance, management counterattacked and blamed burdensome government regulations and unfair foreign competition (Useem, 1993, p. 21). These managerial counterclaims raised doubts about the true cause of America's industrial decline; however, they also opened Pandora's box, by providing an opportunity for social scientists to adjudicate between shareholder claims and managerial claims. The academic community examined shareholder claims of managerial mismanagement against managerial claims of excessive regulations. The vast majority of these findings ruled in favor of the shareholders and, by the middle period, provided a powerful logos argument in support of the takeover wave and against the adoption of takeover defenses (Drucker, 1991, p. 109; Jensen, 1989, p. 65; Useem, 1993, p. 20).

Whereas takeover entrepreneurs provided the pathos appeals of the shareholder perspective, academics provided powerful logos appeals. Management scholars such as Peter Drucker associated the decline of American industry with a managerial class free from the accountability and oversight of shareholder control (Drucker, 1991, p. 109). Financial economists such as Michael Jensen (1989, p. 65) stated that managerial control was causing widespread waste and inefficiency in the public corporation. Academic critics of managerial control were perhaps best epitomized by the Chicago School of Law and Economics, which asserted that in the absence of market failure, markets were better than governments at regulating economic exchange to maximize social benefit. The field of financial economics provided quantitative rigor to these ideas by producing event studies, which gave quasi-scientific support to the efficiency of an active market for corporate control. Event studies were used to quantitatively estimate the costs of adopting takeover defenses, antitakeover laws, and other corporate governance practices (for an extensive review of these studies, see Coates, 1999; Karpoff \& Malatesta, 1989). Event studies showing a negative correlation between share price and impediments to takeovers became an important rhetorical tool for courts, institutional shareholders, and politicians promoting the use of takeovers (Davis \& Thompson, 1994).

For example, in 1987, event studies were used by the College Retirement Equities Fund (CREF), a large institutional fund, to initiate and create a 
campaign against the adoption of the poison pill takeover defense by the firms in its portfolio. The event studies showed that the expected cost to CREF's portfolio was more than the cost of campaigning against the poison pill. Specifically, the event studies showed that the pill would reduce CREF's shares by about $1 \%$ on several billion dollars compared to a campaign against poison pill adoption costing $\$ 10,000$ (Conard, 1984, p. 1472, fn 94; Davis \& Thompson, 1994).

The logos of shareholder rhetoric created allies and sympathizers in important regulatory and judicial positions in society. This promoted an ideological environment where shareholders and the promarket Reagan administration could strongly push for an active market for corporate control. Appointees to the Federal Trade Commission and the federal judiciary were protakeover, decreasing antitrust oversight and increasing intraindustry mergers. Similarly, the Council of Economic Advisors and the Securities \& Exchange Commission (SEC) suggested that an active market for corporate control increased economic efficiency. Furthermore, the Department of Labor's Pension and Welfare Benefits Administration proposed the Employee Retirement Income Security Act of 1974 (ERISA), which mandated that private pension plans increase their fiduciary responsibility by voting proxies and playing a more active role in supervising management (Davis \& Thompson, 1994).

The logos of event studies coupled with the pathos of industrial and national obsolescence produced a powerful rhetorical foundation for the rise of IC logic. Whereas pathos appeals loosened up the social inertia of managerial hegemony, logos kept the engine of social change moving along the trajectory of increased shareholder control and oversight.

\section{Logic and the Residual Claims of Broad Stakeholders Ethos Arguments (1992-1998)}

From 1992 to 1998, the rhetorical appeal of ethos dominated the rhetoric supporting takeover defenses and MC logic. An example of this rhetoric was collected from the interviews:

Increasing shareholder value is the primary goal of the corporation. We adopted takeover defenses as a means to achieve this goal. The problem arises because some directors believe there is a conflict between shareholder value and corporation value. I happen to believe that many things go into generating value, especially long-term value. In the long run, treating communities, shareholders, employees, managers, customers, and suppliers fairly 
and justly is the best way to achieve a high stock price. A director is responsible for protecting all of the firm's stakeholders. Every transaction I've been a party to in the last 5 years has involved nonfinancial considerations, but I don't think any of the companies had it written in their bylaws.

The previous statement resonates with the dominant ethos rhetoric of the late period. Much of the success of this rhetoric developed out of ideas and assumptions of the first scholars attempting to understand the modern corporation. Specifically, Berle and Means (1991) suggested that the notion of managers as the agents of owners was based on a traditional notion of property, where the owner was the controller; however, the modern corporation separated control from ownership. Berle and Means argued that when shareholders gave up control, they also gave up a particular ethos or right to determine unilaterally the fate of the firm. They argued that managerial capitalism had the potential to evolve into a neutral technocracy, where managers balance a variety of claims by various groups in the community, assigning to each a portion of the income stream on the basis of public policy rather than private cupidity.

Moreover, several scholars argued that shareholders were often not the only residual claimants of the firm (Blair, 1995; Coffee, 1986). Many broad stakeholders were conceptualized as having informal promises or residual claims on the firm that were often ignored during a change in control. For example, managers may accept lower levels of compensation early in their careers under the implicit promise that increases in their seniority will translate into higher pay later in their careers. Employees may pick up firmspecific skills or give compensation concessions for promises of long-term employment. Communities may give tax breaks, pollution credits, and/or infrastructure concessions in the hope of future job growth. These informal contracts are common and often understood as implicit agreements between the firm's owners and constituents. Many of these residual claims are embedded within informal social contracts of trust and loyalty. A takeover or change in corporate control often creates situations where these contracts are not honored. Previous owners often do not subtract these liabilities from the price of the firm, and new owners see these claims as ripe for cost cutting.

In response, managerial and stakeholder rhetoric combined to suggest that broad constituents may be residual claimants too. This argument supports MC logic and the idea that managers should run the firm in the best interests of the larger public to ensure that these claims are fairly met. Issues of fairness and justice are often associated with ethos appeals. The 
limited form of this ethos rhetoric suggests that directors are responsible to all stakeholders, insofar as this responsibility benefits (or at least is not harmful to) the shareholders' interests. The expansive form of this ethos rhetoric suggests that directors are responsible to a diverse group of stakeholders and that these broad constituent interests may sometimes take precedence over shareholders' interests. Taken together, the limited and expansive form of this ethos rhetoric supports MC logic and takeover defenses while providing the ideological leverage for broad stakeholders to ally themselves with managers under the logic of MC.

\section{IC Logic-The Rights of Owners and the Restoration of Corporate Democracy Ethos Arguments (1992-1998)}

From 1992 to 1998, the dominant rhetorical appeal criticizing takeover defenses and supporting IC logic was ethos, which is evident in this example collected from the interviews:

Takeover defenses are often justified by the consideration of nonfinancial concerns, but these considerations are basically unfair. Shareholders are the last in line for reimbursement from the firm. Communities receive taxes, employees receive wages, creditors receive interest payments, and so on, and so on, and then the shareholder gets paid. We are elected and legally mandated to maximize shareholder value. Maybe takeover defenses can indirectly increase shareholder value, yet the facts don't support these assumptions. If you adopt these things, your price drops and that's that. I'm here to increase the share price, and in my opinion takeover defenses don't do this. Most takeover defenses are just unfair to shareholders.

The ethos component of the shareholder perspective was based on the sacredness of property rights, democratic ideals of American society, and traditional/nostalgic conceptions of American industrial success. A favorite metaphor of the shareholder perspective described managerial hegemony as a tyranny and shareholders as righteous citizens demanding fair and just representation. The current shareholder democracy was described as a sham and board members (i.e., shareholder's elected representatives) as powerless puppets rubber-stamping decisions and actions proposed by management (Herman, 1981). Managerial capitalism was also described as a self-perpetuating oligarchy that ignored the will of the people and the wisdom of the market. Critics argued that managerial control was inefficient, wasteful, and unjust, and until society returned the control of property to its 
rightful owners, American corporations would underperform both domestically and internationally. In short, the right thing to do was to create a system where management was more accountable to the shareholders and shareholders had a larger voice in corporate decisions (Monks \& Minow, 1991, p. 238).

An excellent example of the manifestation of the shareholder ethos rhetoric was the creation of the Shareholder Bill of Rights. The Shareholder Bill of Rights was produced by the Council of Institutional Investors (CII), a coalition of the largest pension funds controlling more than $\$ 500$ billion in assets. The Shareholder Bill of Rights was endorsed in 1986 by CII as its mandate to give investors a new voice in all fundamental decisions that could affect corporate performance and growth: takeover defense adoption, restructurings, and executive compensation (Davis \& Thompson, 1994). The use of ethos appeals and the metaphor of shareholder democracy gave righteous power and force to earlier pathos and logos appeals. These ethos appeals were metaphorically robust and highly persuasive. In a sense, the shareholder fight for control of the firm was rhetorically associated with the American revolutionary fight for national freedom.

\section{How Rhetoric Shaped the Corporate Institutional Field}

Shareholder, managerial, and broad stakeholder rhetoric helped to shape the competition between MC logic and IC logic and thus the arrangement of the corporate institutional field. Shareholder rhetoric used pathos, logos, and ethos arguments to promote takeovers and to slow the creation and use of takeover defenses. Managerial rhetoric used pathos, logos, and ethos arguments to promote the adoption of takeover defenses and the slowing of takeovers. Broad stakeholder rhetoric combined with managerial rhetoric in the early and late period to help promote the MC logic. Evidence of how rhetoric shaped institutional logics is demonstrated at two levels. At one level, we have the outcomes or actual changes in the diffusion of takeovers and takeover defenses. At another level, we have the use of rhetorical arguments in federal/state legislation and, most important, court rulings. Several important and seminal court rulings were influenced by and contained rhetorical arguments underlying MC logics and IC logics. These court rulings directly influenced the corporate institutional field by defining the relationship between shareholders, managers, and stakeholders, as well as determining the legality and illegality of specific corporate control practices. 


\section{Shareholder Rhetoric in the Court Rulings and Legislation}

Initially uncontested, shareholder rhetoric was extremely successful at propagating the takeover wave and slowing the creation and use of takeover defenses. Before 1987, shareholder rhetoric was virtually unstoppable. The U.S. Supreme Court had not yet legalized state antitakeover laws (see CTS Corp. v. Dynamics Corp. of America, 481 U.S. 69 (1987)), and the takeover wave was spreading at an increasing rate across S\&P 1500. In the Delaware courts, the lawyers for shareholders used the scientific evidence of academic studies to argue the merits of an active market for corporate control (Coates, 1999; Davis \& Thompson, 1994) as well as to present the shareholder rhetoric describing managerial authority as ripe with moral hazards. The courts agreed that managers needed to be held accountable for the effect their decisions had on the owners of the firm (Smith v. Van Gorkom 488 A.2d 858 (Del. 1985)). The ruling in the seminal case Revlon v. MacAndrews and Forbes (506 A.2d 173 (Del 1985)) effectively discouraged takeover defenses and "white knight" strategies by asserting that when the sale of control of a firm was "inevitable," the board's primary duty was to maximize financial return on behalf of its shareholders (Wasserstein, 1998). Shareholder rhetoric was most powerful at the federal level. In the early and mid-1980s, the protakeover Reagan administration and SEC stymied or blocked the vast majority of efforts to regulate takeovers (Davis \& Thompson, 1994; Romano, 1988).

The late 1980s saw a continuation of shareholder success and the logic of investor capitalism. By 1990, more shareholder proposals were passed than in the entire history of shareholder proposals prior to 1990 (Barnard, 1991, p. 1156). Shareholders persuaded federal regulators to increase the range of issues open to shareholder proxy vote as well as to ease restrictions on their ability to coordinate their influence over the firm (Brickely, Lease, \& Smith, 1988; Davis \& Thompson, 1994). The number of antimanagement shareholder resolutions increased from less than 40 in 1987 to 153 in 1991, and shareholder support for anti-poison pill proposals in the average firm increased from 29.4\% in 1987 to $44.8 \%$ in 1991 (Davis \& Thompson, 1994).

\section{Managerial Rhetoric in Court Rulings and Legislation}

Managers responded to the success of shareholder rhetoric. Managerial rhetoric became the central rhetoric promoting the use of takeover defenses, 
arguing that managers were the best stewards of the firm's resources. For example, one important rhetorical strategy was the logos argument that managers should run the firm because managers have superior knowledge. This argument was already a critical underpinning of the Delaware courts' business judgment rule, which stated that the courts would "generally defer to the business judgment of a board of directors," unless there was evidence of "self-dealing or lack of care" (Wasserstein, 1998). In the midst of the 1980s' takeover wave, the Delaware court effectively sanctioned the use of takeover defenses if management perceived a threat to existing corporate governance strategy as long as their defensive measures were "reasonable in relation to the threat posed" (Unocal v. Mesa, 493 A.2d 946 (1985)). This rule, known as the Unocal Standard, governed courts' reviews of takeover defenses throughout the rest of the wave and into the next decade (Paramount Inc. v. Time Inc., 571 A.2d 1140 (Del. 1990)).

Managerial rhetoric also was important for recruiting other constituents to help slow the pace of takeovers. For instance, the pathos argument describing short-term shareholders as raiders stealing the wealth of longterm shareholders was important for promoting takeover defenses approved by the courts to limit shareholder voice, as well as allying managers with some classes of shareholders. Similarly, the managerial rhetoric of ethos opened up space for broad stakeholder rhetoric and the protection of broad constituent claims. In this way, managerial rhetoric helped legitimize the idea that the firm had many constituents and management was responsible for more than just shareholder interests. The powerful combination of managerial and stakeholder rhetoric demonstrates its influence in the courts in the landmark Shamrock v. Polaroid, when the Delaware court allowed an ESOP to be used as a takeover defense (559 A.2d 257 (Del. Ch. 1980)). Moreover, although managerial rhetoric thwarted takeovers internally by promoting the adoption of takeover defenses, this rhetoric also thwarted takeovers externally by lobbying state legislatures to regulate takeovers (Blair, 1995, p. 13; Roe, 1994, p. 152). Managerial rhetoric produced a powerful ideology for effectively attacking and marginalizing shareholder rhetoric (Blair, 1995, p. 13; Roe, 1994, pp. 152-153). Managerial rhetoric effectively raised doubts regarding the efficacy of takeovers as a tool of managerial discipline and thus promoted the dominance of MC logic and continued control of the corporate institutional field by managers (Roe, 1994).

By the early 1990s, efforts by managers and broad stakeholders to thwart the market for corporate control were having a noticeable effect. Fewer U.S. mergers and acquisitions were announced in 1991 than in any year since 1963 (Grimm, 1992), and tender offers decreased significantly in 
1991 (Acquisitions, 1992, p. 25). Although many factors contributed to the slowing of the takeover wave (e.g., the collapse of the junk bond market), state-level antitakeover laws helped speed the process (Davis \& Thompson, 1994; Romano, 1992). Managers and broad constituents were adept at convincing state legislatures that their interests resonated within the antitakeover environment as opposed to the active market for corporate control advocated by shareholders, financial economists, and takeover entrepreneurs (Roe, 1993; Romano, 1987, 1988).

\section{Discussion and Conclusion}

\section{Rhetoric and Institutional Field Dynamics}

This study attempted to analyze how actors linguistically shape the competition of logics within an institutional field. Specifically, we showed how managerial, shareholder, and broad stakeholder rhetoric was used by actors within the corporate institutional field to justify or criticize current corporate institutional field arrangements. We showed how managers and shareholders used pathos, logos, and ethos to support or criticize institutional logics that advocated the adoption of practices that promoted or hindered control of the corporation by managers or shareholders. Although much of this process is still not explained fully, several important insights about rhetoric and institutional field dynamics are suggested by this case study.

For instance, it is notable that both managers and shareholders tended to use the same rhetorical sequence during successive periods of time. Specifically, the institutionalization of the current corporate field arrangement followed a rhetorical sequence where both managers and shareholders resorted to pathos during the earliest years of the takeover wave, then moved to logos, and finally used ethos appeals in the later years. Previous research suggests that this may be a common rhetorical sequence in the institutionalization process (Green, 2004). This trend also suggests that a group's rhetorical strategy may reflect more than their personal choice. Specifically, certain fundamental rhetorical strategies such as pathos, logos, and ethos may result from underlying cultural, historical, or psychological/ cognitive factors.

For example, a psychological/cognitive explanation might suggest that the sequence of institutionalization results from actors' limited attention and cognitive abilities. Movements from the status quo or stable institutional field arrangements are initially brought about by emotional appeals 
that grab and redirect limited social attention. Pathos is needed at the beginning of institutionalization because institutions have an inherent social inertia. Actors within institutions often are not aware of or take for granted the efficacy of present institutional arrangements and practices. Thus, emotional appeals are uniquely attuned to grabbing actors' attention. Once limited social attention is acquired, cognitive and attentive resources are used to make sense of and analyze the best course of action. In this period, rational calculation and logical appeals dominate. Once courses of action are chosen, ethos arguments justify the new institutional field arrangement as morally responsible and appropriate, allowing for the release of limited social attention to deal with other social issues and problems (Green, 2004). In sum, institutionalization processes require the acquisition of limited attention with pathos, the efficient use of limited attention with logos, and the release of limited attention with ethos. ${ }^{4}$

Similarly, the movement from passion, to logic, to morality may also reflect a larger cultural or historical progression that institutional processes follow. For instance, Albert Hirschman described the institutionalization of capitalism as existing initially in a set of cultural descriptions and historical conditions where the activity of "money making" is considered by society as base and a lower level passion of greed and animalistic behavior (Hirschman, 1977). Hirschman (1977) argues that overtime capitalism is ideologically reinterpreted as an activity that can tame or constrain man's lower level passions promoting the triumph of man's reason or logos as well as his morals or ethos. The institutionalization or ideological transformation of capitalism is complete when the act of making money becomes synonymous with morality itself, as Weber (1948/1991) described in the Protestant Ethic and Spirit of Capitalism.

\section{Generalizability and Limitations}

An important limitation of our study is that our interviews are retrospective. Thus, an alternative explanation to the pathos, logos, ethos sequence shaping institutional fields is that social actors use the sequence to give a sense of order to their memory. However, even if our findings are nothing more than postrationalizations, they still tell us something interesting about the production of social memory and construction of history. Future research should test the sequence in real time. An important question our research raises is whether various rhetorical sequences can differentially shape the trajectory and character of institutionalization processes. Our study and analysis is not meant as an exhaustive description of how rhetoric 
shapes institutional field dynamics. Rather, it is meant to highlight the importance of understanding the complex and influential role that communication in general, and rhetoric in particular, plays in the construction and stability of institutional fields. The authors hope that this study spurs further theoretical discussion and empirical analysis regarding the relationship of rhetoric, fields, and historical moments in culture.

\section{Notes}

1. White knight refers to the friendly acquirer of a target firm in a hostile takeover attempt by another firm. The intention of the acquisition is to circumvent the takeover of the object of interest by a third, unfriendly entity, which is perceived to be less favorable.

2. A management buyout (MBO) is a form of acquisition where a company's existing managers acquire a large part or all of the company.

3. KKR stands for Kohlberg Kravis Roberts \& Co., which is one of the world's largest and most successful private equity firms. This firm was responsible for some of the biggest and most well-known takeovers and leverage buyouts of the 1980s.

4. Early institutional theorists argued that institutions are the result of our need to solve problems in the world combined with our inability to comprehend the world in its totality. Institutions are successful solutions providing practices, beliefs, and rules that help us navigate and exist in the world effectively. Given our physical and cognitive limits, it is more efficient for us to ignore our successful solutions and focus limited attention and cognitive abilities on new or more pressing problems. Thus, an efficient use of our cognitive resources leads us to transform our successful solutions into taken-for-granted habits of practice, belief, and rules such as institutions (Homans, 1961).

\section{References}

Acquisitions. (1992). Endangered species of the M\&A market: With the slide of public deals, tender offers got few calls in 1991. Mergers and Acquisitions, 26(6), 25-26.

Aristotle. (1991). The art of rhetoric. New York: Penguin Books.

Bainbridge, S. M. (2004). The business judgment rule as abstention doctrine. Vanderbilt Law Review, 57(1), 81-130.

Baker, G., \& Smith, G. D. (1998). The new financial capitalist. Cambridge, UK: Cambridge University Press.

Barnard, J. W. (1991). Institutional investors and the new corporate governance. North Carolina Law Review, 69, 1135-1187.

Bendix, R. (1963). Work and authority in industry: Ideologies of management in the course of industrialization. New York: Harper \& Row.

Bendix, R. (2001). Work and authority in industry: Managerial ideologies in the course of industrialization. New Brunswick, NJ and London: Transaction Publishing.

Berger, P. L., \& Luckmann, T. (1966). The social construction of reality. New York: Doubleday.

Berle, A. A., \& Means, G. C. (1991). The modern corporation and private property. New Brunswick, NJ: Transaction Publishing.

Bitzer, L. (1968). The rhetorical situation. Philosophy and Rhetoric, 14, 1-14. 
Blair, M. M. (1995). Ownership and control. Washington, DC: Brookings Institution.

Booth, W. (1974). Modern dogma and the rhetoric of assent. Chicago: University of Chicago Press.

Boxenbaum, E., \& Battilana, J. (2005). Importation as innovation: Transposing managerial practices across fields. Strategic Organization, 3(4), 355-383.

Brickely, J. A., Lease, R., \& Smith, C. W. J. (1988). Ownership structure and voting on antitakeover amendments. Journal of Financial Economics, 20, 267-291.

Burke, K. (1969). A rhetoric of motives. Berkeley: University of California Press.

Chandler, A. D. (1977). The visible hand: The managerial revolution in American business. Cambridge, MA: Belknap.

Clemens, E., \& Cook, J. (1999). Politics and institutionalism: Explaining durability and change. Annual Review of Sociology, 25, 441-466.

Coates, J. (1999). The contestability of corporate control: A critique of the scientific evidence on takeover defenses. (Working paper). Cambridge, MA: Harvard University.

Coffee, J. C. J. (1986). Shareholder versus managers: The strain in the corporate web. Michigan Law Review, 85, 1.

Conard, A. F. (1984). The supervision of corporate management: A comparison of developments in European community and United States law. Michigan Law Review, 82, 1472.

Creed, W. E. D., Scully, M. A., \& Austin, J. R. (2002). Clothes make the person? The tailoring of legitimating accounts and the social construction of identity. Organization Science, $13(5), 475-496$.

Davis, G. F. (2005). Social movements and organization theory. New York: Cambridge University Press.

Davis, G. F., \& Stout, S. K. (1992). Organizational theory and the market for corporate control: A dynamic analysis of the characteristics of large takeover targets, 1980-1990. Administrative Science Quarterly, 37, 605-633.

Davis, G. F., \& Thompson, T. A. (1994). A social movement perspective on corporate control. Administrative Science Quarterly, 39(1), 141-173.

DiMaggio, P. (1988). Interest and agency in institutional theory. In L. G. Zucker (Ed.), Institutional patterns and organizations: Culture and environment (pp. 3-21). Cambridge, MA: Ballinger.

DiMaggio, P. J., \& Powell, W. W. (1991). The iron cage revisited: Institutional isomorphism and collective rationality in organizational fields. In W. Powell \& P. DiMaggio (Eds.), The new institutionalism in organizational analysis (pp. 63-82). Chicago and London: University of Chicago Press.

Dobbin, F. R. (1994). Forging industrial policy. Cambridge, UK: Cambridge University Press.

Douglas, M. (1986). How institutions think. Syracuse, NY: Syracuse University Press.

Drucker, P. F. (1991). Reckoning with the pension fund revolution. Harvard Business Review, 69(6), 106-109.

Enteman, W. F. (1989). The ideology of corporate restructuring. In M. E. A. Hoffman (Ed.), The ethics of organizational transformation (pp. 237-234). New York: Quorum.

Faltermeyer, E. (1991, August 26). The deal decade: Verdict on the 80's. Fortune, pp. 58-70.

Fama, E. F. (1980). Agency problems and the theory of the firm. Journal of Political Economy, 88(2), 288-307.

Fligstein, N. (1997). Social skill and institutional theory. American Behavioral Scientist, 40(4), 397-405.

Fligstein, N. (2001). Social skill and the theory of fields. Sociological Theory, 19(2), 105. 
Friedland, R., \& Alford, R. R. (1991). Bringing society back in: Symbols, practices, and institutional contradictions. In W. Powell \& P. DiMaggio (Eds.), The new institutionalism in organizational analysis (pp. 232-263). Chicago and London: University of Chicago Press.

Geertz, C. (1973). The interpretation of cultures. New York: Basic Books.

Gill, A. M., \& Whedbee, K. (1997). Rhetoric. In T. A. Van Dijk (Ed.), Discourse as structure and process: Discourse studies a multidisciplinary introduction (Vol. 1, pp. 157-184). Thousand Oaks, CA: Sage.

Granovetter, M. (1985). Economic action and social structure: The problem of embeddedness. American Journal of Sociology, 91, 481-510.

Green, S. (2001). Rhetoric and the institutionalization of takeover defenses in the S\&P 1500 from 1975-1998. Unpublished doctoral dissertation, Harvard University, Cambridge, MA.

Green, S. (2004). A rhetorical theory of diffusion. Academy of Management Review, 29(4), 653-669.

Greenwood, R., \& Hinings, C. R. (1996). Understanding radical organizational change: Bringing together the old and the new institutionalism. Academy of Management Review, 21(4), 1022.

Grimm, W. T. (1992). Mergerstat review 1991. Schaumburg, IL: Merrill Lynch Business Brokerage \& Valuation.

Haunschild, P. (1993). Interorganizational imitation: The impact of interlocks on corporate acquisition activity. Administrative Science Quarterly, 38, 564-592.

Herman, E. S. (1981). Corporate control, corporate power. New York: Cambridge University Press.

Hirsch, P. M. (1986). From ambushes to golden parachutes: Corporate takeovers as an instance of cultural Framing and institutional integration. American Journal Sociology, 91, 800-837.

Hirschman, A. O. (1970). Exit, voice, and loyalty: Responses to decline in firms, organizations, and states: Cambridge, MA: Harvard University Press.

Hirschman, A. O. (1977). The passions and interests: Political arguments for capitalism before its triumph. Princeton, NJ: Princeton University Press.

Homans, G. C. (1961). Social behavior: Its elementary forms. New York: Harcourt, Brace \& World.

Icahn, C. (1988, February). Icahn on Icahn. Fortune, 29, 54-58.

Jensen, M. C. (1989, September/October). Eclipse of the public corporation. Harvard Business Review, 67, 61-74.

Jensen, M. C., \& Meckling, W. (1976). Theory of the firm: Managerial behavior, agency costs, and ownership structure. Journal of Financial Economics, 3, 305-360.

Karpoff, J., \& Malatesta, P. (1989). The wealth effects of second generation state takeover legislation. Journal of Financial Economics, 25, 291.

Lorsch, J. W. (1989). Pawns or potentates: The reality of America's corporate boards. Boston: Harvard Business School Press.

Manne, H. G. (1965). Mergers and the market for corporate control. Journal of Political Economy, 73, 110-120.

MergerStat. (2004). MergerStat Review: 2004. Santa Monica, CA: FactSet Mergerstat.

Meyer, J., \& Rowan, B. (1991). Institutionalized organizations: Formal structure as myth and ceremony. In W. Powell \& P. DiMaggio (Eds.), The new institutionalism in organizational analysis (pp. 41-62). Chicago: University of Chicago Press.

Mohr, J. (1998). Measuring meaning structures. Annual Review of Sociology, 24, 345-370.

Monks, R. A. G., \& Minow, N. (1991). Power and accountability. New York: Harper Business.

Nohria, N., \& Harrington, B. (1994). The rhetoric of change (Research Note No. 9-494-036). Cambridge, MA: Harvard Business School. 
Perelman, C., \& Olbrechts-Tyteca, L. (1969). The new rhetoric: A treatise on argumentation. Notre Dame, IN: University of Notre Dame Press.

Perrow, C. (1993). Complex organizations: A critical essay (3rd ed.). New York: McGraw-Hill.

Porter, M. (1992). Capital choices: Changing the way America invests in industry. Boston: Council on Competitiveness/Harvard Business School.

Rao, H. (2003). Institutional change in Tocqueville: Nouvelle cuisine as an identity movement in French gastronomy. American Journal of Sociology, 108(4), 795-843.

Roe, M. (1994). Strong managers weak owners: The political roots of American corporate finance. Princeton, NJ: Princeton University Press.

Roe, M. J. (1993). Takeover politics. In M. Blair (Ed.), The deal decade: What takeovers and leverage buyouts mean for corporate governance (pp. 321-380). Washington, DC: Brookings Institution.

Romano, R. (1987). The political economy of takeover statutes. Virginia Law Review, 73, 111-199.

Romano, R. (1988). The future of hostile takeovers: Legislation and public opinion. University of Cincinnati Law Review, 57, 457.

Romano, R. (1992). Rethinking takeover regulation. Journal of Applied Corporate Finance, 5(3), 47-57.

Rosenbaum, V. (1998). Takeover defenses. Washington, DC: Investor Responsibility Research Center.

Scott, W. R. (2001). Institutions and organizations (2nd ed.). Thousand Oaks, CA: Sage.

Seo, M. G., \& Creed, D. (2002). Institutional contradictions, praxis, and institutional change: A dialectical perspective. Academy of Management Review, 27(2), 222-247.

Shleifer, A., \& Summers, L. (Eds.). (1988). Breach of trust in hostile takeovers. Chicago: University of Chicago Press.

Shleifer, A., \& Vishny, R. W. (1986). Large shareholders and corporate control. Journal of Political Economy, 95, 461-488.

Singleton, R. A., Straits B. C., \& Straits, M. M. (1993). Approaches to social research (2nd ed.). New York: Oxford University Press.

Snow, D. A., \& Benford, R. D. (1992). Master frames and cycles of protest. In A. Morris \& C. Mueller (Eds.), Frontiers in social movement theory (pp. 133-155). New Haven, CT: Yale University Press.

Snow, D. A., Rochford, B. E., Worden, S. K., \& Benford, R. D. (1986). Frame alignment processes, micromobilization, and movement participation. American Sociological Review, $51,464-481$.

Strang, D., \& Meyer, J. W. (1994). Institutional conditions for diffusion. In R. W. Scott \& J. W. Meyer (Eds.), Institutional environments and organizations: Structural complexity and individualism (pp. 100-111). Thousand Oaks, CA: Sage.

Suchman, M. C. (1995). Managing legitimacy: Strategic and institutional approaches. Academy of Management Review, 20, 571-610.

Suddaby, R., \& Greenwood, R. (2005). Rhetorical strategies of legitimacy. Administrative Science Quarterly, 50, 35-67.

Taylor, F. W. (1911). The principles of scientific management. New York: Harper.

Thornton, P. H., \& Ocasio, W. (1999). Institutional logics and the historical contingency of power in organizations: Executive succession in the higher education publishing industry, 1958-1990. American Journal of Sociology, 105, 801-844.

Tillman, B. (1989). Hostile takeovers and defensive tactics policy considerations. Unpublished master's thesis, Harvard University, Cambridge, MA. 
Useem, M. (1993). Executive defense: Shareholder power and corporate reorganization. Cambridge, MA: Harvard University Press.

Useem, M. (1996). Investor capitalism: How money managers are changing the face of corporate America. New York: Basic Books.

Votaw, D. (1965). Modern corporations: Englewood Cliffs, NJ: Prentice Hall.

Wasserstein, B. (1998). Big deal. New York: Warner Books.

Weber, M. (1991). From Max Weber: Essays in sociology (H. H. Gerth \& C. W. Mills, Trans.). London: Routledge. (Original work published 1948)

Weston, F., Chung, K., \& Siu, J. (1990). Takeovers, restructuring, and corporate governance. Upper Saddle River, NJ: Prentice Hall.

Sandy Edward Green Jr. (PhD, Harvard University, 2001) is an assistant professor in the Marshall School of Business at the University of Southern California. His main research interests include rhetoric, neo-institutional theory, corporate governance, and stock market bubbles.

Marin Babb (JD candidate, Stanford University, 2010; BS, Business Administration, BA, English, University of Southern California 2006) is a student at Stanford Law School and a research assistant at the University of Southern California. Her research interests include corporate law and policy.

C. Murat Alpaslan ( $\mathrm{PhD}$, University of Southern California, 2004) is an assistant professor in the College of Business and Economics at California State University, Northridge. His main research interests include corporate governance, stakeholder theory, and crisis management. 